\title{
Cognitive linguopoetics of lyric prose texts
}

\author{
Elena Ozerova ${ }^{1 *}$,Oleg Fedoszov ${ }^{2}$ \\ ${ }^{1}$ Belgorod State National Research University, 308015 Belgorod, Pobedy, 85, Russian Federation \\ ${ }^{2}$ Eötvös Lorand University, Uszoda u.50, H-1173 Budapest, Hungary
}

\begin{abstract}
The article examines the cognitive specificity of lyric prose texts as a product of discursive activity. The semantic space of lyric prose texts decodes images of cultural memory as an interpretive category of cognitive linguopoetics. The meaning-generating mechanisms of lyric prose texts are focused on reflecting the ego-perception of reality, which explicates the cultural and value attitudes of the author. In cognitive linguopoetics, architectonics represents the semantic essence and integrity of the lyric prose text, since it is a discursive and pragmatic manifestation of its semantic continuum. Through the prism of the architectonics of the text, the associative-figurative tonality of the semantic content of the artistic text is decoded. That is why the concept of architectonics integrates two principles: a) the creative-discursive potential of text generation and b) a multi-vector palette of discursive consciousness, which is motivated by the experience of lyrical speech thinking. The essence of lyric prose texts is determined by the lyrical architectonics of sensory-emotional and aesthetic integrity, which is motivated by poetic reflexems, representing a discursively conditioned scan of reality, passed through the prism of expressive-figurative perception of the egotope.
\end{abstract}

\section{Introduction}

Cognitive linguopoetics actualizes the study of the value-semantic representation of reality through the refraction of the subjective sensory perception of the world. It should be noted that the theoretical aspects of cognitive linguopoetics are in their infancy, therefore they are represented by various scientific approaches (D. N. Akhapkin, V. P. Grigoriev, A. Kamalova, A. A. Lipgard, K. Oatley, T.B. Radbil, O.G. Revzina, P. Stockwell, I.A. Tarasova, R. Tsur, M. Freeman).

The purpose of the study is to conduct a cognitive-hermeneutic analysis of the nationalcultural and semantic space of lyric prose texts and to identify the vectors of verbalization of the artistic word.

\section{Methods and results}

We developed a special method of cognitive-hermeneutic analysis of lyric prose texts. It includes the interpretation of historical and cultural content, helps to establish patterns of

\footnotetext{
*Corresponding author: ozerova@bsu.edu.ru
} 
semantic realization of the text and allows to identify vectors of verbalization of the artistic concept. In total, we analyzed 807 prose works and identified about 4500 contexts of lyric prose.

The research results can be used to create a text research methodology based on the value-cognitive, hermeneutic and cultural dominants of the artistic word. This approach to cognitive linguopoetics of lyric prose texts actualizes the registers of sensory perception of reality in the process of generating a text.

Cognitive poetics in the texts of lyric prose is aimed at identifying the cognitive base of sensory perception of reality, focusing the author's lyrical consciousness and contributing to the generation of lyricoprosaic text. For our research, it is fundamentally important to write this term together, which is due to the subordinate connection of a complex word parts.

By lyricoprosaic text we mean "a product of discursive activity: a prosaic form work of a lyric genre, filled with the author's sensual perception of life" [Ozerova, 2012, p. 10], since the images reflect "much that is not contained in them, where an allegory appears even without the author's intent or in spite of him" [Potebnya, 1976, p. 373].

No less relevant for cognitive linguopoetics is the understanding of the semantic content of a lyricoprosaic text, which in the process of narration, according to the concept of M. Poster, "is thought of as devoid of any ontological support and arising in an act of purely subjective effort" [https://dic.academic.ru/dic.nsf/history_of_philosophy/326]. At the same time, Wolf Schmid, considering prose as poetry, notes that the reduction of psychologism, the nondiscrimination of subject and object, associative nonlinear intratextual connections are indicators of prose as poetry [see: Schmid, 1998].

The lyrical word refers to the concept of "poetics", denoting verbal creativity. The theory of verbal creativity has long been trying to learn the laws governing human poetic activity. Initially, poetics was raised to the doctrine of the architectonics (construction) of the artistic word - the subject of literary criticism. Then, within its framework, linguopoetics began to form. Since it is charged with the study of the poetic language and the system of pictorial and expressive means of an artistic text, the term architectonics began to enrich with new meanings. As one penetrates into the deep essence of the semantics of a figurative word, architectonics acquires a synonymous meaning with respect to its internal organization, called poetic structure. The word as the main element of speech architectonics is an aesthetically motivated component of the figurative-aesthetic palette of a single artistic whole created by the author. The selection and syntagmatic fixation of the word in the lyrical form of artistic speech is determined by the semantic, discursive, associative-figurative and aesthetic potential of architectonics.

In our concept of cognitive linguopoetics, the meaning of the architectonics of an artistic word is interpreted as a harmonious combination in its associative-image trajectory of various semantic elements: a) cognitive-pragmatic, b) discursive-modus, c) semantic (linguistic), d) aesthetic-stylistic. Moreover, they are not only projected, but also enriched by the discursive consciousness of the author, reader and characters.

Cognitive poetics in the texts of lyric prose is characterized by the following features.

1. The dominant role in the generation of lyrical architectonics belongs to the egotop as an anthropocentric marker of the subjective-individual reproduction of reality.

Egotop demonstrates the integrative essence of the author's I as an integral valuesemantic perception of reality, which is encoded by the subjective intentions of the lyric prose text author.

The object and subject of the egotop are an integrative synthesis of all streams of the author's lyrical worldview, thanks to which lyric prose is able to focus the value-semantic, mental-moral meanings generated by the process of cognition and refracted through the prism of the author's I. 
Egotop as a carrier of cognitive knowledge, apperceptive nominations, cultural and linguistic values, author's intentions fills the semantic field of the text with lyrical universals through the prism of subjective worldview. The cognitive factors of linguopoetics are manifested in the architectonics of lyric prose texts through the verbalization of poetic phraseological units, the functioning of which activates the following processes 1) the metaphorization of individual author's combinations, 2) the cognitive potential of a lyricoprozaic text subject, 3) the apperceptive nomination of objectified cultural meanings in the process of generating the text.

The linguopoetics of the lyric prose text demonstrates a complex cognitive-connotative system, the anthropocentricity of which is formed by the egotop, which generates the discursive-modus architectonics of the word. The nature of the modulo-cognitive architectonics of a word is conditioned by the discursive canons of speech generation, since the semantics of a verbal sign is determined by a peculiar configuration of meaning and sense [Alefirenko, 2009, p. 90-91]. Therefore, the processes of understanding [Dyck, 2000, p. 12] are associated with decoding the lyrical essence of a sign produced in the artistic text by a verbalized discursive-modus concept, which is a cognitive substrate of a word. The linguistic way of such decoding is the identification in the content of the associative-image sign of the patterns of integration in its meaning of discursive-modus meanings. The problem of interpreting verbal imagery is based on the understanding of the speech uniqueness of the associative- image sign and the polysemy of the interpretation of the discourse that generates it.

2. The problem of apperceptive nomination and interpretation of the characters' inner speech, which explicates the anthropocentric focus of the author's worldview, is significant for the texts of lyrical prose, since the author's apperceptive intentions are conditioned by subjective experiences caused by the perception of reality.

Variations in the apperceptive nomination form a value-cultural combination of implicit meanings, which are revealed with the help of the author's cognitive intentions. In the subjective-individual perception of reality, certain ego-meanings are revealed, which give rise to sensory-objective images. In Jung's interpretation, feelings differ both in fact and value-wise, since they demonstrate "the process that takes place between the ego and some content, moreover, the process that gives the content a certain value ..." [Jung, 1995, p. 579].

The functioning of inner speech in a lyricoprozaic text is based on intrapersonal communication and demonstrates the conjugation of the author's value universals. In inner speech, reality is reflected through apperceptive nomination and is a connecting link through which the reader decodes the cognitive registers of understanding the texts of lyric prose: "in the process of perceiving the artistic work based on background knowledge and textual references" [Semino, 2009, p. 56] there is a semantic exchange of information between the addresser and the addressee.

The integrating factor of apperceptive nomination and internal speech is the perceptual and mental activity of the author and the reader, in the process of which both the generation of meaning and the perception of the text take place. The linguistic means that form such interaction include verbal paradigms, deminitive constructions and lexical repetitions, with the help of which a lyrical image is formed that promotes empathy. Experiencing as the most important psycho-emotive component of the cognitive structure of lyric prose texts contributes to the connection of individual experience and the image world, therefore, the functioning of apperceptive nomination and inner speech demonstrate a complex palette of cognitive and emotive experience of the egotop, which is the center of the generation and perception of the text.

3. Mental engrams accumulate cognitive and cultural knowledge and are transformed into lyrical images. The cognitive activity of the author's thinking makes it possible to 
form a subjective worldview in symbols and images, representing the cognitive and mental registers of ethnocultural knowledge (engrams), which accumulate the value-semantic focus of cultural memory. Cultural memory is explicated in past memories and generates a holistic cognitive structure, actualized, as a rule, by figurative components: Christmas snow lace, Trinity - smells like a green grove, birch light air.

In the discourse of a lyricoprozaic text, memory transforms the past into images. In the linguistic space of memory, the activity of consciousness is transmitted through the lyrical transformation of images and predetermines the communicative interaction of the addresser and addressee of lyric prose texts.

Lyric-prose text is not only artistic modeling, but also the creation of a monocentric synergetic unity of its reproduction through the prism of empathy between the author and the reader. Note that, characterizing the object of cognitive poetics, Peter Stockwell defines it as "the natural process of reading" [Stockwell, 2002, p. 2].

Cognitive linguopoetics combines lyric and mental-cultural potential as a generating dominant of lyrical prose texts, which contributes to the associative revival of sensory experiences, stored in memory, which "are not the preservation or restoration of our past, but always a new, always transformed past" [Berdyaev, 1994, p. 285]. The interaction of lyrical means and culture is due to the unity of mental values, the integrity of the cultural thesaurus, the sign and symbolic architectonics of the narrative.

Mental engrams as components of cultural memory are saturated with the individual lyrical content of a linguistic personality, as a result of which cultural and linguistic memory is formed, which programs the patterns of generating the value-semantic space of lyric prose texts.

The functioning of poetic phraseological units is due to the individual author's semantic variations, thanks to which the process of generating and perceiving a text demonstrates the cognitive activity of the author and the reader. The specificity of poetic phraseological units creation is manifested in the possibility of generating a figurative combination through a concentrated metaphorical meaning.

Lyric prose texts are the product of discursive activity and represent the result of the author's imaginative intentions. The analysis of semantic interpretation reveals the valuesemantic panorama of the text and allows to understand how the realities of mental content combine cognitive and linguistic resources of consciousness.

The semantic space of lyric prose texts decodes images of cultural memory as an interpretive category of cognitive linguopoetics. The meaning-generating mechanisms of lyric prose texts are focused on reflecting the ego-perception of reality, which explicates the cultural and value attitudes of the author. The ability to decode and interpret the author's intentions is provided to the reader as the bearer of the mental and cultural continuum.

Cognitive linguopoetics of lyric prose texts reveals the discursive factors of interaction between cognitive and linguistic phenomena, which are motivated by the sensory-creative perception of reality and are reflected in the linguistic consciousness of the addresser using the architectonics of the narrative.

In cognitive linguopoetics, architectonics represents the semantic essence and integrity of the lyric prose text, since it is a discursive and pragmatic manifestation of its semantic continuum. Through the prism of the architectonics of the text, the associative-figurative tonality of the semantic content of the artistic text is decoded. That is why the concept of architectonics integrates two principles: a) the creative-discursive potential of text generation and b) a multi-vector palette of discursive consciousness, which is motivated by the experience of lyrical speech thinking. For the modeling of the architectonics of the lyric prose text, the cognitive and emotive resources of the author's lyric thinking are of great importance. Consequently, the architectonics of lyric prose texts demonstrates the 
value-semantic specificity of the lyric prose discourse, which is actualized by moral dominants, sensory perception of reality, representation of the egotop as an explicator of the "I". This interaction reveals the uniqueness of the lyrically sublime language functioning and the cognitive motivation of the addresser of prosaic universes.

The architectonics of lyric prose texts is conditioned by the emotional and aesthetic perception of the associative-figurative activity of the author and the reader. The discursive-modus architectonics of the word is a kind of convergence of the architectonics of discursive consciousness and the architectonics of the text generated by it, embodied in the artistic thinking of the author and the reader. Moreover, the discursive-modus architectonics of the word is not formed by the configuration of any verbalized elements of a communicative event, but only those that accumulate aesthetic completeness and an associative-image scale of lyric prose texts.

Lyric-prose texts are able to convey the sensibility and cognitive knowledge of the author's worldview. This kind of philosophical experiences of the authors of lyricoprozaic texts make it possible to conceptually link into a single panoramic picture all the discursive manifestations of lyric prose both at the anthropological level of self-disclosure of the essence of discourse and at the level of its linguocultural significance [Lomakina, 2018, p. 45].

\section{Conclusion}

When modeling the discursive-modus architectonics of lyric prose texts, dominant personal meanings are revealed, which are verbalized by linguistic means of expressing subjectivity.

Comprehension of one's own "I" is manifested in the architectonics of lyric prose texts through subjective-individual perception of reality, inner speech, apperceptive nomination, connotative variations.

The architectonics of lyricoproziac speech is a structure of extreme complexity: in relation to the architectonics of the artistic prose language, it is significantly complicated by implicit cognitive-discursive transformations.

The narrative of the lyricoproziac text is conditioned by the idea of introducing subjective meanings. Consequently, for the cognitive linguopoetics of lyricoproziac texts, the judgment of Fredrick Jameson is relevant - the narrative syntagmatics "creates reality" [Jameson, 2014, p. 244].

The reader, involved in the process of perception and understanding of the world with the help of the author's explicit and implicit linguistic representation, plunges into the psychological world of experienced impressions, perceptions and memories of the addresser, thereby getting involved in the process of decoding the lyric I. "Emotional and sense perception of the world is considered a peculiar feature of the Russian mentality" [Ozerova, 2019, p. 331].

The essence of lyric prose texts is determined by the lyrical architectonics of sensoryemotional and aesthetic integrity, which is motivated by poetic reflexes, representing a discursively conditioned scan of reality, passed through the prism of expressive-figurative perception of the egotope.

Cognitive linguopoetics actualizes the linguopoetic nature of the text, its verbalconceptual and value-semantic architectonics, reflects the author's interpretation of reality in the reader's perception.

\section{Acknowledgments}

This paper was financially supported by the Russian Foundation for Basic Research, grant No. 20-012-22046. 


\section{References}

1. E.G. Ozerova, Russian lyricopathic text: discursive and cognitive aspect: monograph, (NIU «BelGU» Publ., Belgorod, 2012) (in Russ.)

2. A.A. Potebnya, Aesthetics and poetics (Nauka Publ., Moscow, 1976) (in Russ.)

3. M. Poster, Narrative. URL:https://dic.academic.ru/dic.nsf/history_of_philosophy/326

4. V. Shmid, Ornament - poetry - myth - subconscious, Prose as poetry. Pushkin Dostoevsky - Chekhov - avant-garde, pp. 297-308, Saint Petersburg Publ. (1998) (in Russ.)

5. N.F. Alefirenko, "Living" Word: Problems of Functional Lexicology (Flinta Nauka Publ., Moscow, 2009) (in Russ.)

6. T.A. Deik van, Language. Cognition. Communication, B.: BGK im. I.A. Boduena de Kurtene Publ., p. 308 (2000)

7. K.G. Yung, Psychological types, Saint Petersburg: «Yuventa» Moscow: «Progress Univers» Publ., p. 717 (1995)

8. E. Semino, Text Worlds Cognitive Poetics: Goals, Gains and Gaps Eds. G. Broone, J. Vandaele. Berlin; N.Y.: Mouton de Gruyter, pp. 33-71 (2009)

9. P. Stockwell, Cognitive poetics: An Introduction. London and New York (2002)

10. N.A. Berdyaev, Free Spirit Philosophy (Respublika Publ., Moscow, 1994)

11. O.V. Lomakina, The Use of Phraseological Units as an Attribute of L.N. Tolstoy's Language Personality (Based on the Analysis Experience of the Speech from the Author and Characters of Works of Fiction) Cuadernos de Rusística Española, Granada: Universidad de Granada, Vol. 14, p. 39-47 (2018)

12. F. Dzheimison, Marxism and the interpretation of culture, translation from English in Moscow: Ekaterinburg: Kabinetnyi uchenyi Publ., p. 414 (2014)

13. E.G. Ozerova, N.F. Alefirenko, S.A. Kosharnaya, Mental Representations of Lyrical Prose Research in Applied Linguistics, 10, Special Issue: Proceedings of the 6th International Conference on Applied Linguistics Issues (ALI 2019) July 19-20, 2019, Saint Petersburg, Russia, 2019, pp. 324-332 (2019) 